\title{
3. Der Stringansatz im Spektrum der Quantengravitationstheorien
}

Auch wenn der Stringansatz manchem seiner Verfechter vielleicht schon als ausgefeiltes Instrumentarium zur Verwirklichung des physikalischen Vereinheitlichungsprogramms erscheinen mag, stellt er noch keine wirkliche physikalische Theorie dar. ${ }^{137}$ Es fehlt sowohl die Einsicht in die ihm zugrundeliegenden fundamentalen Prinzipien als auch, konsequenterweise, eine eindeutige nomologische Grundlage. Das zur Zeit als Stringansatz formierende polymorphe Konvolut besteht infolge dieses Mangels aus einer grossen Anzahl disparater Elemente, deren gegenseitige Bezüge nicht immer vollständig klar sind und die sich auch nicht notwendigerweise allesamt in einen gemeinsamen konzeptionellen Rahmen einbringen lassen. Es handelt sich nicht um eine physikalische Theorie, sondern vielmehr um eine nicht immer vollständig überschaubare, relationale Vernetzungsstruktur von physikalischen Konzepten und Ad-hoc-Annahmen, modelltheoretischen Ideen, mathematischen Prozeduren und mehr oder weniger im Verborgenen wirkenden metaphysischen Intuitionen.

Der Stringansatz ist jedoch der bisher am weitesten ausformulierte der noch nicht gescheiterten oder ad acta gelegten Ansätze zu einer Theorie der Quantengravitation. Ihr einziger zur Zeit ernstzunehmender Konkurrent auf diesem Feld ist die "Loop Quantum Gravity", eine Weiterentwicklung der Kanonischen Quantengravitation. ${ }^{138}$ Die Loop Quantum Gravity kann im Bereich konzeptioneller Ideen und Entwicklungen ebenso wie der Stringansatz einige Erfolge verzeichnen. Aber hinsichtlich empirisch überprüfbarer Resultate steht es um sie nicht besser als um den Stringansatz.

Das heisst, es gibt zur Zeit keine vollständig ausformulierte oder gar etablierte Theorie der Quantengravitation, mittels derer sich die Allgemeine

137 Seine recht labyrinthisch erscheinende Ausformulierung, die im Rahmen eines in mancher Hinsicht kuriosen Theorienbildungsprozesses erreicht wurde, wird in Kap. 4.1. im Einzelnen zu erörtern sein.

138 Einen Überblick über die verschiedenen zur Zeit existierenden Ansätze zu einer Theorie der Quantengravitation (auch die exotischeren) gibt etwa Rovelli (1998). 
Relativitätstheorie und die Quantenmechanik bzw. die Quantenfeldtheorien konzeptionell oder nomologisch zusammenführen liessen:

"We should emphasize at the outset that currently there is no quantum theory of gravity in the sense that there is, say, a quantum theory of gauge fields. 'Quantum gravity' is merely a placeholder for whatever theory or theories eventually manage to bring together our theory of the very small, quantum mechanics, with our theory of the very large, general relativity. [...] However, there do exist many more-or-less developed approaches to the task - especially superstring theory and canonical quantum gravity." (Callender / Huggett (2001 a) 3)

Um den Stringansatz in seinen Voraussetzungen und Konsequenzen besser beurteilen zu können und um seine konzeptionellen Unterschiede und Bezüge etwa zur Loop Quantum Gravity einschätzen zu können, ist es jedoch sinnvoll, einen Blick auf das Spektrum der grundsätzlichen konzeptionellen Möglichkeiten zu werfen, die sich für die Formulierung einer Theorie der Quantengravitation bieten könnten.

\section{Das Spektrum der Alternativen}

Die grundlegendste Motivation der Ansätze zu einer Theorie der Quantengravitation besteht, wie schon im einleitenden Kapitel erörtert, im Wunsch, die konzeptionellen Konflikte zwischen der Allgemeinen Relativitätstheorie und der Quantenmechanik bzw. den Quantenfeldtheorien zu beseitigen. Zur Realisierung dieses Ziels (bzw. um ihm abzuschwören) bieten sich grundsätzlich sehr unterschiedliche Strategien: ${ }^{139}$

1. Strategie: Quantisierung der Allgemeinen Relativitätstheorie.

Bei der Quantisierung der Allgemeinen Relativitätstheorie geht es einzig und allein um die Herstellung ihrer konzeptionellen, modelltheoretischen Vereinbarkeit mit der Quantenmechanik bzw. den Quantenfeldtheorien. Dies impliziert nicht notwendigerweise eine nomologische Vereinigung aller Wechselwirkungen.

139 Vgl. auch Butterfield / Isham (2001) sowie Kiefer (1994). 
Es gibt für die Quantisierung der Allgemeinen Relativitätstheorie zwei verschiedene Ansätze:

(i) die Kovariante Quantisierung, ein (erfolgloser) ausschliesslich perturbativer Ansatz, der versucht, die Methodologie der perturbativen Quantenfeldtheorien auf die Gravitation zu übertragen, ${ }^{140}$

(ii) die Kanonische Quantisierung, ein grundlegend nicht-perturbativer Ansatz zur Erfassung der Quantengravitation, der nach seiner Reformulierung zur Loop Quantum Gravity mutiert ist. ${ }^{141}$

2. Strategie: Suche nach einer Theorie der Quantengravitation, die gleichzeitig eine vereinheitlichte Quantentheorie aller Wechselwirkungen ist und sich durch Quantisierung einer anderen klassischen Theorie als der Allgemeinen Relativitätstheorie ergibt.

Die diesem Ansatz zugrundeliegende Idee ist die, dass die Quantisierung der Gravitation nur im Rahmen einer nomologischen Vereinigung aller Wechselwirkungen erreicht werden kann - so wie die schwache Wechselwirkung sich erst gemeinsam mit der elektromagnetischen Wechselwirkung konsistent beschreiben liess. Die Anforderungen an einen solchen Ansatz bestehen nicht zuletzt darin, dass er die Allgemeine Relativitätstheorie und das quantenfeldtheoretische Standardmodell als niederenergetische Näherungen enthalten sollte.

Die einzig bekannte Ausprägung dieser Strategie liegt mit den perturbativen Stringtheorien vor. Hier resultiert die Quantisierung der Gravitation gemeinsam mit der quantentheoretischen Erfassung aller anderen Wechselwirkungen aus der Quantisierung einer klassischrelativistischen Stringdynamik.

3. Strategie: Suche nach einer Theorie der Quantengravitation, die eine vereinheitlichte Quantentheorie aller Wechselwirkungen ist, aber nicht durch die Quantisierung einer klassischen Theorie zustandekommt.

Die Idee, eine nomologische Vereinigung aller Wechselwirkungen im Rahmen einer Quantentheorie zu erreichen, die man nicht dadurch erhält, dass man eine klassische Theorie quantisiert, liegt etwa dem 
"Computational Universe Model" von Seth Lloyd zugrunde. ${ }^{142}$ Hierbei soll sich die Gravitation - gemeinsam mit allen anderen Wechselwirkungen - aus fundamentalen Quantencomputationen und ihren relationalen Bezügen ableiten lassen. Die Raumzeit als Ausdruck der Gravitation wäre diesem Ansatz zufolge ein abgeleitetes Konzept. Auch eine nicht-perturbative Weiterentwicklung des Stringansatzes könnte in diese Richtung führen. ${ }^{143}$

4. Strategie: Entwicklung einer neuartigen Nicht-Quantentheorie zur Beschreibung des Substrats der physikalischen Wirklichkeit.

Wenn alle Ansätze, welche die Quantenmechanik voraussetzen und die Quanteneigenschaften der Wirklichkeit auch auf ihrer fundamen-

142 Siehe Lloyd (2005). Lloyds Ansatz lässt sich als Weiterentwicklung von Wheelers "It from bit"-Konzeption (vgl. Kap. 1. und weiter unten) ansehen.

"The theory proposed here differs from conventional approaches to quantum gravity such as string theory, canonical quantization, loop quantum gravity, and Euclidean quantum gravity in that it does not set out to quantize gravity directly. The only thing that is quantum here is information: gravity arises out of the underlying quantum computation. [...] Normally, quantization of a physical theory proceeds from the 'top down': one starts with a classical theory and applies established quantization procedures to derive a quantum mechanical version of the theory. By contrast, the theory proposed here is a 'bottom up' approach to quantum gravity: we start with an underlying quantum mechanical system, a quantum computation, in which the quantum dynamics are completely established. We then derive a geometry - or more precisely, a quantum superposition of geometries - from the computation, and show that each of the geometries in the superposition obeys a discretized version of General Relativity. The virtue of this approach is that all observed phenomena flow directly from the 'mother computation', whose underlying quantum dynamics is straightforward and easily analyzed." (Lloyd (2005) 2f)

Die Struktur der gravitativen Wechselwirkung, wie sie sich in der Allgemeinen Relativitätstheorie darstellt, ergibt sich dabei geradezu von selbst:

"Since the way that information is processed in a quantum computation is independent of the embedding in spacetime, any dynamical laws that can be derived from the computation are automatically generally covariant. Since general covariance [...] implies Einstein's equations, the geometry induced by the computational universe obeys Einstein's equations [...]." (Lloyd (2005) 7)

Das gleiche gilt für die nomologische Vereinigung aller Wechselwirkungen:

"The computational universe model is intrinsically a theory of quantum matter coupled to gravity, and not a theory of either quantum matter or quantum gravity on its own." (Lloyd (2005) 13)

Siehe Kap. 6. 
talsten Ebene als Grundgegebenheit ansehen, hartnäckig scheitern sollten, wäre zu überlegen, ob sich eine konzeptionelle oder eine nomologische Vereinheitlichung in der Beschreibung der Wechselwirkungen vielleicht nur mit einer Theorie erreichen lässt, die keine Quantentheorie im herkömmlichen Sinne mehr ist. ${ }^{144}$

\section{Strategie: Alternative Auffassung (vermeintlicher) nomologischer} Strukturen in der Natur.

Hierbei handelt es sich nicht um eine Strategie zum Erreichen einer Theorie der Quantengravitation oder irgendeiner anderen fundamentalen physikalischen Beschreibung, sondern vielmehr um die Strategie $\mathrm{zu}$ einer Therapie, die helfen soll, Ambitionen auf eine fundamentale Beschreibung zu überwinden, indem sie zur Einsicht in ihre Vergeblichkeit führt.

Die Grundidee: Vielleicht ist die scheinbare Nomologie der Natur eine Folge unserer wissenschaftlichen Methodologie, unserer epistemischen Perspektive oder unseres mesokosmischen Ausgangspunkt. Vielleicht gibt es in der Natur selbst keine exakte, sondern bestenfalls eine approximative nomologische Regularität, die möglicherweise das Ergebnis statistischer Effekte ist und nur für den Niederenergiebereich Relevanz besitzt. Diese statistisch bedingte oder konstruktiv gewonnene approximative Nomologizität würde uns nicht bis $\mathrm{zu}$ einer strukturierten Substratebene führen können.

So etwas hatte beispielsweise John Wheelers mit seiner "Law-withoutLaw"-Physik im Sinn, deren Grundzüge sich auch noch in seinem späteren "It-from-Bit"-Konzept wiederfinden: ${ }^{145}$

$144 \quad \mathrm{Zu}$ dieser Strategie gibt es nur (gescheiterte oder nicht zu Ende gebrachte) historische Vorläufer: Einstein hatte (wenngleich unter anderen Voraussetzungen) mit seiner Einheitlichen Feldtheorie ganz sicher so etwas im Sinn. Und auch John Wheelers frühe Ansätze zu einer umfassenden Geometrodynamik, einer konsequenten Umsetzung des Einsteinschen Programms einer Geometrisierung aller Wechselwirkungen, verkörperte Aspekte dieser Strategie. Nach dem Scheitern dieses umfassenden Geometrisierungsprogramms gibt es wohl keine konkrete und explizit ausformulierte Entwicklung in Richtung auf eine fundamentale Nicht-Quantentheorie.

$145 \quad$ Siehe Wheeler (1979), (1983) und (1989). 
"Four no's / No tower of turtles / No laws / No continuum /

No space, no time." (Wheeler (1989) 354)

Weiter ausgearbeitet wurde diese Idee, unabhängig von Wheeler, von Holger B. Nielsen im Rahmen seiner "Random Dynamics". ${ }^{146}$ Demnach gibt es auf der fundamentalen Ebene der Wirklichkeit keine Regularitäten. Das Substrat ist völlig chaotisch. Die Strukturen, die sich für den Niederenergiebereich herausfiltern lassen, sind das Ergebnis statistischer Interpolationen. Die Theorien, die diesen Niederenergiebereich und seine Strukturen beschreiben, besitzen bestenfalls den Status effektiver Theorien. Das chaotische Substrat selbst lässt keine strukturierte nomologische Erfassung zu. Jede formulierbare Nomologie bleibt eine Näherung und beruht auf einer spezifischen methodologischen Herangehensweise, welche die Modalitäten der jeweiligen Näherung festlegt. Sie bleibt insofern letztlich immer ein Konstrukt der Wissenschaft. Die Suche nach einer fundamentalen Theorie mit regulären nomologischen Strukturen wäre unter diesen Bedingungen zum Scheitern verurteilt. Jede Theorie mit dem Anspruch, reguläre Substratstrukturen auszuzeichnen, wäre bestenfalls eine Extrapolation von rein instrumentellem Wert und ohne deskriptive Implikationen. ${ }^{147}$

Werfen wir nach diesem Panorama einen etwas genaueren Blick auf die Ansätze zur Quantisierung der Allgemeinen Relativitätstheorie, also die 1. Strategie. Denn in diesem Kontext findet sich die Loop Quantum Gravity, der vorrangige und interessanteste Konkurrent des Stringansatzes.

\footnotetext{
146 Siehe Nielsen (1983), Frogatt / Nielsen (1991) sowie Nielsen / Rugh / Surlykke (1994).

147 Eine solche Theorie könnte niemals realistisch interpretiert werden. Sie liesse sich bestenfalls als konstruktives mathematisches Schema verstehen, aus dem die Strukturen der Niederenergiephysik sich formal ableiten liessen, ohne dass diese Ableitung den Gegebenheiten in der Natur entspräche. Eine solche Theorie wäre also bestenfalls ein mathematisches Instrument zur Reproduktion der Niederenergiephysik, nicht aber eine Beschreibung des Substrats.
} 


\section{Kovariante Quantisierung}

Das Programm der Kovarianten Quantisierung ${ }^{148}$ zielt auf eine perturbative Quantisierung der vierdimensionalen Raumzeit-Mannigfaltigkeit der Allgemeinen Relativitätstheorie ab. Die gekrümmte vierdimensionale Riemannsche Mannigfaltigkeit wird dabei als Summe aus einer rein kinematischen Hintergrundmetrik und einer dynamischen Störung dieser Hintergrundmetrik behandelt. Der Störungsanteil entspricht formal dem zu beschreibenden dynamischen Feld. Für dieses werden, im Sinne der perturbativen Quantenfeldtheorien, Operatorfelder definiert. Es bleibt innerhalb der Kovarianten Quantisierung bei dieser perturbativen Behandlung der Dynamik des Störungsanteils der Metrik. Die Kovariante Quantisierung liefert für die Dynamik der Gravitonen, der Anregungszustände des Gravitationsfeldes, ein Bild, das dem der Wechselwirkungsquanten innerhalb des Standardmodells der Quantenfeldtheorie entspricht: Die Gravitonen bewegen sich auf der gewählten festen Hintergrundmetrik. Feynmansche Gravitonengraphen liefern die Grundlage für eine Entwicklung nach Potenzen der Gravitationskonstanten.

"Field-theoretic techniques are put at the forefront. The first step in this program is to split the space-time metric $g_{m n}$ in two parts, $g_{m n}=$ $n_{m n}+V G h_{m n}$, where $n_{m n}$ is to be a background, kinematical metric, often chosen to be flat, $G$ is Newton's constant, and $h_{m n}$, the deviation of the physical metric from the chosen background, the dynamical field. The two roles of the metric tensor are now split. The overall attitude is that this sacrifice of the fusion of gravity and geometry is a moderate price to pay for ushering-in the powerful machinery of perturbative quantum field theory. [...] it is only $h_{m n}$ that is quantized. Quanta of the field propagate on the classical background space-time with metric $n_{m n}$. If the background is in fact chosen to be flat, one can use the Casimir operators of the Poincare group and show that the quanta have spin two and rest mass zero. [...] Thus, in this program, quantum general relativity was first reduced to a quantum field theory in Minkowski space." (Ashtekar (2005) 5)

148 Siehe etwa DeWitt (1967a) und (1967b). 
Die kovariante Quantisierung als rein perturbativer Ansatz scheint jedoch unabwendbar mit dem Problem der Nicht-Renormierbarkeit belastet zu sein und hat, wie schon in der Einleitung erläutert, zu keinen Erfolgen geführt. Dies ist nicht verwunderlich, wenn man berücksichtigt, dass die Dynamik der Raumzeit sich nur schwerlich durch störungstheoretische Näherungen auf der Grundlage einer fixierten Hintergrundmetrik annähern lassen wird, und, dass die Identität von Gravitation und den metrischen Eigenschaften der Raumzeit, wie sie in der Allgemeinen Relativitätstheorie zum Ausdruck kommt, eine Quantisierung auf einer Hintergrundraumzeit ohnehin sehr fragwürdig macht. ${ }^{149}$

\section{Kanonische Quantisierung}

Eine Alternative zur perturbativen Kovarianten Quantisierung und ihren Problemen bietet vielleicht die Kanonische Quantengravitation, eine strikt nicht-perturbative Quantentheorie ausschliesslich des Gravitationsfeldes. ${ }^{150}$ Ausgangspunkt ist hierbei die Zerlegung der vierdimensionalen RaumzeitMannigfaltigkeit in dreidimensionale raumartige Hyperflächen und Zeitparameter. Die Auszeichnung des Zeitparameters ist in diesem Ansatz erforderlich zur Definition des kanonischen Impulses für die hamiltonsche Behandlung in der Quantisierung. Das Ergebnis dieser Quantisierung ist die Wheeler-DeWitt-Gleichung ${ }^{151}$, eine zeitlose Null-Energie-Schrödingergleichung. Diese ist grundsätzlich nicht störungstheoretisch behandelbar. Leider hat sich aber auch keine andere Methode finden lassen, so dass sie sich in ihrer ursprünglichen Form als mathematisch nicht ohne weiteres traktibel erwiesen hat.

Man hatte das Programm der Kanonischen Quantengravitation schon für aussichtslos erachtet, als sich schliesslich doch noch eine Lösung abzeichnete. Diese beruhte auf der Einsicht, dass die Wahl geeigneter kanonischer Variabler in der zu quantisierenden klassischen Theorie für die kanonischen Vertauschungsrelationen in der Quantisierung entscheidend ist. Die

\footnotetext{
$149 \quad$ Vgl. Kap. 6.

150 Wie schon in der Kovarianten Quantisierung wird mit der Kanonischen Quantisierung keine Vereinigung der Wechselwirkungen angestrebt.

151 Siehe DeWitt (1967).
} 
ursprüngliche, der Wheeler-DeWitt-Gleichung zugrundeliegende Formulierung der kanonischen Variablen hatte hier gerade in die Sackgasse geführt. 1986 gelang Abhay Ashtekar ${ }^{152}$ die Formulierung eines Satzes neuer kanonischer Variablen für die klassische Allgemeine Relativitätstheorie. Mit den Ashtekar-Variablen, die auf raumzeitlichen Konnektionen mit Spineigenschaften beruhen und auf deren Grundlage sich die Allgemeine Relativitätstheorie als Eichtheorie darstellt, liessen sich für deren Quantisierung schliesslich methodische Verfahren aus den Quantenfeldtheorien nutzbar machen.

"On the relativity side, the third stage began with the following observation: the geometrodynamics program laid out by Dirac, Bergmann, Wheeler and others simplifies significantly if we regard a spatial connection - rather than the 3-metric - as the basis object. [...] these were 'spin-connections', required to parallel propagate spinors, and they turn out to simplify Einstein's equations considerably. [...] Perhaps the most important advantage of the passage from metrics to connections is that the phase-space of general relativity is now the same as that of gauge theories. [...] One could now import into general relativity techniques that have been highly successful in the quantization of gauge theories. [...] Since the canonical approach does not require the introduction of a background geometry or use of perturbative theory, and because one now has access to fresh, non-perturbative techniques from gauge theories, in relativity circles there is a hope that this approach may lead to well-defined, non-perturbative quantum general relativity [...]." (Ashtekar (2005) 8f)

Die Einführung der Ashtekar-Variablen führte konsequenterweise zu einer Neuverhandlung der Kanonischen Quantengravitation und schliesslich zur Loop Quantum Gravity.

152 Siehe Ashtekar (1986) und (1987). Siehe auch Sen (1982). 


\section{Loop Quantum Gravity}

Die vor allem von Abhay Ashtekar, Lee Smolin und Carlo Rovelli entwickelte Loop Quantum Gravity ${ }^{153}$ ist eine Form der Kanonischen Quantengravitation, die von einer Weiterentwicklung der Ashtekar-Variablen ausgeht. Sie beruht nicht auf einer unmittelbaren Quantisierung der Metrik der Raumzeit, sondern ist eine Quantentheorie raumzeitlicher Konnektionen bzw. eichtheoretischer Holonomien (Wilson-Loops). ${ }^{154}$

"More precisely, in this approach one begins by formulating general relativity in the mathematical language of connections, the basic variables of gauge theories of electro-weak and strong interactions. [...] the emphasis is shifted from distances and geodesics to holonomies and Wilson loops. Consequently, the basic kinematical structures are the same as those used in gauge theories. A key difference, however, is that while a background space-time metric is available and crucially used in gauge theories, there are no background fields whatsoever now. Their absence is forced upon us by the requirement of diffeomorphism invariance (or 'general covariance')." (Ashtekar (2005) 14)

Die Loop Quantum Gravity greift also Prinzipien und Methoden aus den Quantenfeldtheorien auf, jedoch ohne deren problematischere Implikationen zu übernehmen. Sie arbeitet insbesondere ohne Hintergrundraum und behandelt die Raumzeit als dynamische Entität.

"[...] LQG [Loop Quantum Gravity] is a straightforward quantization of GR [General Relativity] with its conventional matter couplings. [...] On the other hand, LQG has a radical and ambitious side: to merge the conceptual insight of GR into QM [Quantum Mechanics]. In order to achieve this, we have to give up the familiar notions of space and time. The space continuum 'on which' things are located and the time 'along which' evolution happens are semiclassical appro-

153 Siehe Ashtekar et al. (1992), Rovelli (1997), (1998), (2005), Thiemann (2001) sowie Smolin (2004b).

154 Ashtekar sieht die Traditionslinien folgendermassen:

"The covariant approach has led to string theory and the canonical approach developed into loop quantum gravity." (Ashtekar (2005) 10)

Die Loop Quantum Gravity bezieht zudem Ideen ein, die auf Penroses Twistor-Ansatz zurückgehen. Siehe Penrose (1967) und (2004). 
ximate notions in the theory. [...] The price of taking seriously the conceptual novelty of $G R$ is that most of the traditional machinery of QFT [Quantum Field Theory] becomes inadequate. This machinery is based on the existence of background spacetime, and GR is the discovery that there is no background spacetime." (Rovelli (2004) 10)

Die Loop Quantum Gravity ist ein topologischer und grundlegend nichtperturbativer Ansatz. Sie ist eine Theorie, in der sich die Raumzeit als auf grundlegender Ebene diskret darstellt:

"[...] in quantum gravity the notion of spacetime disappears in the same manner in which the notion of trajectory disappears in the quantum theory of a particle." (Rovelli (2004) 21)

Die Diskretheit der Raumzeit wird jedoch nicht als Voraussetzung in die Theorie hineingesteckt, sondern ist ihr Ergebnis:

"Space itself turns out to have a discrete and combinatorial character. Notice that this is not imposed on the theory, or assumed. It is the result of a completely conventional quantum mechanical calculation of the spectrum of the physical quantities that describe the geometry of space." (Rovelli (2004) 14)

Die quasi-kontinuierliche, klassische Raumzeit erweist sich als eine makroskopische Konsequenz der Konnektionen:

"One finds that, at the Planck scale, geometry has a definite discrete structure. [...] space-time continuum arises only as a coarse-grained approximation." (Ashtekar (2005) 9)

Auf der Planck-Ebene liegt sie in Form diskreter Konnektionen und Spinnetze vor:

"In the quantum theory, the fundamental excitations of geometry are most conveniently expressed in terms of holonomies. They are thus one-dimensional, polymer-like and in analogy with gauge theories, can be thought of as 'flux lines' of electric fields/triads. More precisely, they turn out to be flux lines of area [...]. [...] if quantum geometry were to be excited along just a few flux lines, most surfaces would 
have zero area and the quantum state would not at all resemble a classical geometry. [...] semi-classical geometries can result only if a huge number of these elementary excitations are superposed in suitable dense configurations. The state of quantum geometry around you, for example, must have so many elementary excitations that approximately $10^{68}$ of them intersect the sheet of paper you are reading. Even in such states, the geometry is still distributional, concentrated on the underlying elementary flux lines. But if suitably coarsegrained, it can be approximated by a smooth metric. Thus, the continuum picture is only an approximation that arises from coarse graining of semi-classical states." (Ashtekar (2005) 16)

Die Zeit ist in der Loop Quantum Gravity Ausdruck der Umgruppierung der Spinnetze, wobei die Zeittakte nur lokal wirksam sind:

"The main novelty is that dynamics treats all physical variables (partial observables) on the same ground and predicts their correlations. It does not single out a special variable called 'time', to describe evolution with respect to it. Dynamics is not about time evolution, it is about relations between partial observables." (Rovelli (2004) 265)

Die in die Loop Quantum Gravity einfliessende Diffeomorphismus-Invarianz der Allgemeinen Relativitätstheorie führt zur Koordinatenunabhängigkeit der Darstellung. In ihr wird, nach Ansicht der Vertreter der Loop Quantum Gravity, die Relationalität der Raumzeit deutlich:

"Spacetime itself is formed by loop-like states. Therefore the position of a loop state is relevant only with respect to other loops, and not with respect to the background." (Rovelli (2004) 12)

Materieteilchen werden im Kontext der Loop Quantum Gravity als Zustände des Spinnetzes behandelt. Sie entsprechen bestimmten Knotentypen. Felder sind ebenso Zustände des Spinnetzes. Sie entsprechen Graphenattributen.

Die vordergründigen Probleme der Loop Quantum Gravity sind zumindest teilweise ähnlich gelagert wie die des Stringansatzes. Es gibt bisher keine konkreten numerischen Vorhersagen und mithin keine empirischen Überprüfungsmöglichkeiten; und die Theorie ist bisher alles andere als eindeu- 
tig formulierbar. ${ }^{155} \mathrm{Im}$ Gegensatz zum Stringansatz ist mit der Loop Quantum Gravity jedoch keine nomologische Vereinigung der Wechselwirkungen intendiert. Es geht ausschliesslich um die konzeptionelle Vereinbarkeit unserer Beschreibung der Gravitation mit denen der anderen Wechselwirkungen.

Einer der schwerwiegendsten konzeptionellen Kritikpunkte am Ansatz der Kanonischen Quantisierung - und damit an der Loop Quantum Gravity besteht darin, dass sie Raum und Zeit in ihrem Formalismus aufspaltet und damit wichtige Einsichten der Relativitätstheorie unberücksichtigt lässt:

"[...] identifying the causal structure, is skirted in canonical quantum gravity by positing a split of spacetime into space and time at the outset. [...] the diffeomorphism group [...] is represented in a distorted way in the canonical theory, so that it is unclear that one is actually quantizing general relativity at all." (Weinstein (2001) 98)

Das daraus resultierende Probleme ist zur Zeit noch ungelöst.

"The most speculative, underdeveloped research cops up in the covariant extension of loop gravity. The natural extension gives a sumover-paths twist on loop gravity leading to a notion of a 'Quantum Spacetime', known as 'Spinfoam'. The full theory is then a sum-overspinfoames. The boundary of a spin-foam is a spin-network." (Rickles (2005) 27)

Vielleicht lässt sich eine Lösung dieses Problems nur im Rahmen eines Ansatzes erreichen, der nicht von einer Quantisierung der Allgemeinen Relativitätstheorie, sondern von einer grundlegenderen Quantentheorie der Raumzeit ausgeht und die Raumzeit der Allgemeinen Relativitätstheorie als klassischen Grenzfall, nicht jedoch als Ausgangspunkt einer Quantisierung, enthält:

"More generally, one might step outside the framework of canonical, loop quantum gravity, and ask why one should only quantize the metric. [...] it may well be that the extension of quantum theory to general relativity requires one to quantize, in some sense, not only the me-

155 Dies geht nicht zuletzt auf die Vieldeutigkeit in der Wahl des Hamilton-Operators zurück. 
tric but also the underlying differential structure and topology. This is somewhat unnatural from the standpoint where one begins with classical, canonical general relativity and proceeds to 'quantize' (since the topological structure, unlike the metric structure, is not represented by a classical variable). But one might well think that one should start with the more fundamental, quantum theory, and then investigate under which cirumstances one gets something that looks like a classical spacetime." (Weinstein (2005) 10)

\section{Synthese aus Stringansatz und Loop Quantum Gravity?}

Stringansatz und Loop Quantum Gravity sind zur Zeit im wesentlichen vollständig getrennte Forschungsprogramme. Ersterer wird mit sehr grossem Personalaufwand vorangetrieben, letztere mit recht kleinem. Es gibt nur ganz wenige Theoretiker, die an beiden Strategien arbeiten. Zumindest einige Vertreter der Loop Quantum Gravity sehen in dieser strikten Trennung der Forschungsprogramme, die das gemeinsame Ziel einer Beschreibung der Quantengravitation verfolgen, ein Problem:

"[...] it is still true that almost all work in quantum gravity nowadays is carried out strictly within the context of one research program or another. [...] I want to convey [...] that this is counterproductive, and that progress from this point on will be faster if more people can think in terms of a single, 'quantum theory of gravity under construction', which will have elements of more than one of these programs." (Smolin (2000a) 2)

Da die beiden Forschungsprogramme, was ihre partiellen Erfolge betrifft, in mancher Hinsicht zueinander komplementär sind, läge es nahe, mögliche Synergieeffekte auszunutzen, die vielleicht in einer tendenziellen Zusammenführung der Programme erzielt werden könnten:

"String theory and loop quantum gravity are remarkably complementary in their successes, and one may speculate that they could merge or that some technique could be transferred from one to the other. In particular, loop quantum gravity is successful in dealing with the 
nonperturbative background-independent description of quantum spacetime, which is precisely what is missing in string theory, and loops might provide some tool to string. A loop, of course, is not a very different object from a string. String theory can be formulated as a sum over world-sheets, and loop quantum gravity can be formulated as a sum over surfaces." (Rovelli (1998) 22)

Erste Anzeichen für eine Konvergenz zeichnen sich vielleicht schon ab: ${ }^{156}$

"Finally, and extremely speculatively, we note that both superstring theory and the canonical programme have evolved greatly from their initial formulations, and, as far as we are aware, it is possible that they are converging in some way: for example, perhaps some descendent of the Ashtekar formulation will turn out to be a realization of $M$ Theory. That is, the future may reveal an analogy between the historical developments of quantum gravity and the Schrödinger and Heisenberg formulations of quantum mechanics." (Callender / Huggett (2001 a) 20)

Nach diesem kleinen Exkurs in die Landschaft der strategischen Alternativen zum Erreichen einer Theorie der Quantengravitation, und nach der grundsätzlichen Ortsbestimmung des Stringansatzes innerhalb dieses Spektrums, kommen wir nun auf diesen selbst, seine Entwicklung, seine Implikationen und seine Probleme zurück:

$156 \quad$ Siehe auch Kap. 6. 
